\title{
International insights into the consequences of COVID-19 on consumption and attitudes towards savings
}

\author{
Renáta Machová ${ }^{1}$, Enikő Korcsmáros ${ }^{1}$, Monika Esseová $^{1,{ }^{*}}$, and Roland Marča ${ }^{1}$ \\ ${ }^{1}$ J. Selye University, Faculty of Economics and Informatics, Komárno, Slovakia
}

\begin{abstract}
Research background: The coronavirus has impacted the global economy as many businesses had to close due to the restrictions, and people's spending and saving behaviour have changed. According to the negative consequences of the COVID-19, people reconsider their expenditures and rearrange their savings. To avoid the spread of infection, several employers switched to a home office where it was possible. As a result of working from home in numerous cases, monthly housing expenditures have increased. To prevent the spread of the disease, a great number of people tried not to appear in crowded places. Therefore, online shopping came to the fore.

Purpose of the article: The main purpose of the article is to give a comprehensive picture of the relationship between the respondents' job losses and their attitudes towards savings. Furthermore, the association was analysed, and its strength and direction were measured between the increased monthly housing expenditures and the reconsideration of shopping intentions. Moreover, the association was examined between the decreased spendings on commuting and the frequency of online shopping.

Methods: The research was conducted among residents in two neighbouring V4 countries, Slovakia and Hungary. To analyse the formulated hypotheses, a nonparametric Pearson's chi-square test and Somers' delta tests were used. Findings \& Value added: Thanks to the results, it can be declared for both countries that there is an association between job losses due to the pandemic and saving behaviour. Based on Somers' $d$ test, there is a positive correlation between spending less on commuting and online shopping frequency and increased housing expenditures and shopping reconsideration between the respondents.
\end{abstract}

Keywords: consumer behaviour; savings; spendings; households

JEL Classification: D10; D14; E21

\footnotetext{
*Corresponding author: monika.esseova36@gmail.com
} 


\section{Introduction}

The known consequences of globalization, such as the fact that markets have become global or the role of international trade has become greater and the spread of diseases much faster, have become even more observable during the coronavirus epidemic. As a result of globalization, the needs of consumers have also changed, as goods have become much more accessible to people demographically. Due to the pandemic, shopping habits changed worldwide, panic shopping was observed, and online shopping came to the fore due to closures and working from home. For many people working from home has led to an increase in their monthly expenditures as their consumption has increased. In contrast, there were also people who paid close attention to this, so either their consumption did not increase or in some cases even decreased. Following the outbreak, unemployment has risen significantly globally. It is for this reason that people have begun to reconsider their intention to buy and their savings. Based on Balcerowicz-Szkutnik (2018), the consumption determines one's status in the society, this fact is generally exploited by sellers. We can observe that many times people buy goods only to show they can afford to purchase them. This led to the development of a completely different kind of consumption and saving behaviour. As a result of the epidemic, this consumer behavior began to fade. During the pandemic, there were strict restrictions in Slovakia, which had a serious impact on the country's economy. For this reason, we chose to analyse its consequences on the mentioned factors in Slovakia and in one neighbouring country.

\section{Theoretical framework of our research}

Due to the rapid spread of the coronavirus and its globally felt effects, the immediate response of consumers, both in terms of consumption and savings, wasn't surprising. As a result, their attitude to the recession has changed (Roth and Wohlfart, 2020). Savings have become a feature, and demand for commodities that have not been considered particularly important during difficult times has decreased. Based on Furnham and Cheng's statistical results (2019), we can state that mostly three factors influence consumer savings. These factors are the following: Emotional stability, Conscientiousness and Openness. We reckon that emotional stability is the most affected factor during the pandemic because millions of people lost their job, with it their income, and the high mortality rate, the closures, and the distance from family caused depression in many people. Conscientiousness can be influenced by one's financial intelligence and government's activities. The openness to previous experience could help to find a rational attitude towards savings.

From the consumer behaviour point of view, the decision-making process plays an extremely important role. Examining this phenomenon, we can observe how different factors such as money, time, and emotional or mental states influence them. In most situations, the decisions made by the consumers are influenced by myriad factors like family, price, brand, lifestyle. During difficult times, the demand for fundamental goods can easily increase, so in these cases, the first and foremost influencing factors are family and psychological factors against other factors like price and brand (Dulam et al., 2021). An increase in the intention of saving for households, financial precautions, and the reconstruction of the savings have tended to be an economic consequence of the pandemic (Jordà et al., 2021).

Based on Rodgers's study (2020), we can conclude that paid family leave can affect household savings too. According to his results, we can state that paid family leave does not necessarily increase the family savings. The money received in this way is not conditionally set aside by individual families for future use. On the other hand, in many cases from that amount of money, the parents can benefit their child in terms of purchasing some babyrelated products. From our point of view, in these difficult times, paid family leave plays a 
particularly important role in the lives of families and their savings. During the times of the pandemic, it is extremely important to use this money in the correct way, as the families with newborn babies may be way more vulnerable than before. Based on Pascual-Saez et al's. (2019), data which were obtained from the World Bank's subsamples we can state that savings in the European countries are significantly impacted by myriad factors. As claimed by this research, old-aged dependency has a highly negative impact on savings. This should be reduced by the government's old-age support programs. During the increasing income inequality the government should simultaneously understand better how income can help to get a better allocation of mentioned resources. On the other hand, the government should work for a better-coordinated pension system, especially in the Euro area. From our point of view, as a result of the rapid spread of the COVID-19, the elderly were the first to be most at risk, so they were the ones who tended to panic buying. Those who have low pensions were afraid of an increase in food prices due to shortages of goods and distribution problems. Another reason for the hoarding is that they tried to avoid the crowded places in order to prevent infection.

According to Binder's research (2020), many consumers suspended their travel plans and started to buy sustainable food as they were afraid of being infected with COVID-19. This fact is also supported by Navickas et al., (2020), as from their point of view, the travel decision-making is connected with the available information for the tourists. The tourism sector is significantly affected during these times, and the tourists are highly vulnerable. As claimed by Silva et al. (2020), age plays a key role in terms of expenditures. In general, younger visitors spend less in all expenditure categories. The younger tourists spend way less on different things such as accommodation, transportation, or restaurants. Plausibly, this can be highly traced back to their savings. We reckon that many people have started to use their savings for different reasons, during the pandemic, for instance for living as many people lost their jobs. Thus, probably the younger tourists will spend less money on tourism purposes. Based on a representative research conducted in Poland by Borkowski et al. (2020), the individual travel time was reduced by $66 \%$ in all age groups. They pointed out that from the student's point of view, the total travel time had decreased by $80 \%$. A worth mentioning fact is that those jobs which did not change at all have also reported a $50 \%$ total travel time decrease which can be traced back to the reduced travel time for leisure and shopping. Based on evidence from a research paper written by Beck and Hensher (2020), we can observe a higher increase in planned activities towards online shopping and recreation although the use of public transport has significantly decreased. As claimed by them, home-office working became an important factor to reduce the spread of the COVID-19 by avoiding the use of public transport. They found out that a great number of respondents liked the work from home with different employer support. From our perspective, during difficult times it is essential to make decisions that prevent the spread of the virus and aim to protect human life. However, it is important to mention that the myriad types of work do not allow working from home. In these cases, the employers should focus on reducing the spread of the virus at the workplace. This can be achieved by basic rules such as continuous ventilation, wearing masks and keeping a proper distance. Nevertheless, it is worth mentioning the need to encourage workers to take the COVID vaccination, as thanks to this way we are more likely to return to the pre-pandemic period. Shamshiripour et al. (2020) found out in their research that $71 \%$ of their participants had not worked from home before the outbreak of the new pandemic, while $15 \%$ of them were already working from home. Furthermore, we can conclude that $37 \%$ of their respondents had not worked from home for a single day during the COVID-19. We believe that the frequency of online purchases could increase as people save money on commuting to work. Considering these trends, the consumers' habits could completely change. 


\section{Methods}

The purpose of this study is to collect data and information about the association between job losses due to the pandemic and saving behaviour, the increased monthly housing expenditures and the reconsideration of shopping intention, the decreased spendings on commuting and the frequency of online shopping. The examination was conducted thanks to the online and paper-based survey among Slovak and Hungarian citizens. The research is based on a cross-sectional method hence, we took a single sample of the elements of the population once. We obtained the required data from 862 respondents. The proportion of Hungarian respondents to Slovak respondents was about 348 to 514, which indicates $40.37 \%$ and $59.63 \%$ percentages. After the data collecting it can be observed that there was a greater willingness by women to participate in our research, as $54.03 \%$ of the Hungarian respondents were women and $45.97 \%$ men. Similarly, $50.77 \%$ of the Slovak respondents were women and $49.23 \%$ men. The data acquisition was performed between January 2021 and March 2021. From our survey we used 6 questions out of 24 closed questions to analyse our purposes. In order to draw conclusions and results on the whole sample, it is vital to calculate the required sample size. Based on Wiley (1999), with the help of sample size calculation we can determine the ideal sample size. For this reason, we used the following formula:

$$
n=\frac{z^{2} \mathrm{P}(1-\mathrm{P})}{d^{2}}
$$

where $\mathrm{n}=$ sample size $=15190136$ according to ŠÚSR (2020) and KSH (2021), critical value at $95 \%$ confidence level, $\mathrm{Z}=1.96, \mathrm{P}=$ expected prevalence or proportion $=40 \%=0.4$, and $\mathrm{d}=$ precision $=5 \%=0.05$. Based on the obtained value of the calculation, 369 respondents could be sufficient to apply the results for the whole sample. According to the above-mentioned value of respondents, our research with the 862 respondents is representative.

Our first hypothesis is the following:

H0: There is no significant relationship between respondents' job losses due to the pandemic and their attitudes towards savings.

H1: There is a significant relationship between respondents' job losses due to the pandemic and their attitudes towards savings.

According to Walker and Ugoni (1995), we can state that in our first hypotheses our variables are measured on a nominal measurement level, hence, we used Pearson's chi-square test to determine whether there is an association between the analysed variables. In our hypothesis test, the job losses due to the pandemic were marked as an independent variable, whereas the attitudes towards savings were marked as a dependent variable. In the first variable we defined two categories and within the latter variable we defined three categories. It is important to point out that observations must be independent, so none of our answers can be included in multiple cells at once. As an important requirement, up to $20 \%$ of the cells can have less than five expected values. In our analysis we meet both of the requirements, so we can perform the test. During the examination we work with a $5 \%$ significance level, which means that there is a 5\% chance to reject the correct null hypothesis.

Our second and the third hypotheses are the following:

H0: There is no association between the increased monthly housing expenditures and shopping reconsideration.

H2: There is an association between the increased monthly housing expenditures and shopping reconsideration.

H0: There is no association between spending less on commuting and the frequency of online shopping. 
H3: There is an association between spending less on commuting and the frequency of online shopping.

Based on Somers (1962), to analyse and measure the strength and direction of the association and the relationship itself that exists between two ordinal variables, we can use Somers' delta nonparametric test to examine our aims. To perform Somers'd test, we need to reconsider two assumptions which are the following: We have one dependent variable and one independent variable, and both are measured on an ordinal scale. In our case, we meet this requirement for both hypotheses as both of the variables are measured on a 5-point Likert scale, where 1 represented, not typical at all, and 5 represented fully typical. To perform the test, we need to reconsider one more assumption, which is the following: There should be a monotonic relationship between the analysed variables. In this case of the assumption, it is important to mention that typically it is not possible to analyse this assumption when running the test. However, we assume that the value of the variables increases together or when one value increases, the other decreases.

\section{Results and Discussion}

In the following part of our article, we analysed the three formulated hypotheses.

In our first hypothesis we examined the association between respondents' job losses due to the pandemic and their attitudes toward savings. For this purpose, Pearson's chi-square test was used to analyse the association.

Table 1. Pearsons's chi-square test for both countries

\begin{tabular}{|l|r|r|r|r|r|}
\hline & \multicolumn{1}{|c|}{$\begin{array}{c}\text { Value } \\
\text { SK }\end{array}$} & \multicolumn{1}{|c|}{$\begin{array}{c}\text { Value } \\
\text { HU }\end{array}$} & df & $\begin{array}{c}\text { Asymptotic } \\
\text { Significance } \\
\text { (2-sided) - SK }\end{array}$ & $\begin{array}{c}\text { Asymptotic } \\
\text { Significance (2- } \\
\text { sided)- HU }\end{array}$ \\
\hline Pearson Chi-Square & 15.123 & 7.942 & 2 & 0.001 & 0.019 \\
\hline Likelihood Ratio & 13.597 & 8.104 & 2 & 0.001 & 0.017 \\
\hline Linear-by-Linear Association & 13.458 & 7.420 & 1 & 0.000 & 0.006 \\
\hline N of Valid Cases & 154 & 68 & & & \\
\hline
\end{tabular}

Source: Own elaboration (2021)

After performing the Pearson's chi-square test, we can conclude that there is a significant association between the examined variables in both countries, as the significance level for Slovakia is $\mathrm{p}=0.01(<0.05)$, and for Hungary $\mathrm{p}=0.019(<0.05)$. To measure the strength of the association we used Cramer's V coefficient.

Table 2. Cramer's V coefficient

\begin{tabular}{|l|l|r|r|r|r|}
\hline \multicolumn{2}{|l|}{} & $\begin{array}{c}\text { Value - } \\
\text { SK }\end{array}$ & $\begin{array}{c}\text { Value - } \\
\text { HU }\end{array}$ & $\begin{array}{c}\text { Approximate } \\
\text { Significance - } \\
\text { SK }\end{array}$ & $\begin{array}{c}\text { Approximate } \\
\text { Significance - HU }\end{array}$ \\
\hline $\begin{array}{l}\text { Nominal by } \\
\text { Nominal }\end{array}$ & Phi & 0.313 & 0.342 & 0.001 & 0.019 \\
\cline { 2 - 6 } & Cramer's V & 0.313 & 0.342 & 0.001 & 0.019 \\
\hline \multicolumn{2}{|l|}{ N of Valid Cases } & 154 & 68 & & \\
\hline
\end{tabular}

Source: Own elaboration (2021)

A chi-square test of independence was conducted for both countries between respondents' job losses and their attitudes toward savings. All expected cell frequencies were greater than five. There was a statistically significant association between respondents' job losses due to 
the pandemic and their attitudes toward savings, $\chi^{2}(2)=15.123, p<0.005$ and $\chi^{2}(2)=$ $7.942, \mathrm{p}<0.005$ The association was moderately strong (Cohen, 1998), Cramer's V $=0.313$ (Slovakia) and 0.342 (Hungary). Based on the results for both countries, we accept the alternative hypothesis and reject the corresponding null hypothesis.

In our second hypothesis we analysed the association between the increased monthly housing expenditures and shopping reconsideration. In the case of the second and third hypothesis we meet both assumptions which was discussed in the method part of our work. In our research we have conducted the asymmetric version of Somers'd tests. First and foremost, it's worth mentioning that based on Somers (1962), and Liebetrau (1983), the value of Somers's d can range from -1 to +1 , which indicates the direction and strength of the association. A value of -1 indicates that the observations are discordant, whilst +1 means that all pairs of observations are concordant.

Table 3. Directional Measures (Hungary) - Somers'd test

\begin{tabular}{|l|l|l|r|r|r|r|}
\hline \multicolumn{2}{|l|}{} & Value & $\begin{array}{c}\text { Asymptotic } \\
\text { Standard } \\
\text { Error }\end{array}$ & $\begin{array}{c}\text { Approx. } \\
\text { T }\end{array}$ & Approx. Sig. \\
\hline $\begin{array}{l}\text { Ordinal } \\
\text { by } \\
\begin{array}{l}\text { Ordinal } \\
\text { Ord }\end{array}\end{array}$ & $\begin{array}{l}\text { Somers' } \\
\text { d }\end{array}$ & $\begin{array}{l}\text { Symmetric } \\
\text { housing } \\
\text { expenditures have }\end{array}$ & 0.499 & 0.036 & 13.490 & 0.000 \\
\cline { 2 - 7 } & $\begin{array}{l}\text { I reconsider my } \\
\text { shopping Dependent }\end{array}$ & 0.519 & 0.480 & 0.036 & 13.490 & 0.000 \\
\hline
\end{tabular}

Source: Own elaboration (2021)

In case of Hungary, Somers'd test was run to determine the assocation increased housing expenditures and shopping reconsideration amongst 348 participants from Hungary. There was a strong, positive correlation between the analysed variables, which was statistically significant $(\mathrm{d}=0.519, \mathrm{p}<0.005)$.

Table 4. Directional Measures (Slovakia) - Somers'd test

\begin{tabular}{|c|c|c|c|c|c|c|}
\hline & & & Value & $\begin{array}{l}\text { Asymp. } \\
\text { Stand. } \\
\text { Error }\end{array}$ & $\begin{array}{c}\text { Approx. } \\
\mathrm{T} \\
\end{array}$ & $\begin{array}{c}\text { Approx. } \\
\text { Sig. }\end{array}$ \\
\hline \multirow{3}{*}{$\begin{array}{l}\text { Ordinal } \\
\text { by } \\
\text { Ordinal }\end{array}$} & \multirow{3}{*}{$\begin{array}{l}\text { Somers' } \\
\text { d }\end{array}$} & Symmetric & 0.417 & 0.033 & 12.082 & 0.000 \\
\hline & & $\begin{array}{l}\text { My monthly housing } \\
\text { expenditures have } \\
\text { increased Dependent }\end{array}$ & 0.402 & 0.033 & 12.082 & 0.000 \\
\hline & & $\begin{array}{l}\text { I reconsider my } \\
\text { shopping Dependent }\end{array}$ & 0.434 & 0.034 & 12.082 & 0.000 \\
\hline
\end{tabular}

Source: Own elaboration (2021)

In case of Slovakia, Somers'd test was run to determine the assocation increased housing expenditures and shopping reconsideration amongst 514 participants from Slovakia. There was a strong, positive correlation between the analysed variables, which was statistically significant $(d=0.434, p<0.005)$. Based on the obtained results we accept the alternative hypothesis and reject the corresponding nullhypothesis for both countries.

In our third hypothesis we analyse the association between spending less on commuting and online shopping frequency. 
Table 5. Directional Measures (Hungary) - Somers'd test 2

\begin{tabular}{|c|c|c|c|c|c|c|}
\hline & & & Value & $\begin{array}{l}\text { Asymp. } \\
\text { Stand. } \\
\text { Error }\end{array}$ & $\begin{array}{l}\text { Approx. } \\
\text { T }\end{array}$ & $\begin{array}{l}\text { Approx. } \\
\text { Sig }\end{array}$ \\
\hline Ordinal & Somers' & Symmetric & 0.322 & 0.048 & 6.757 & 0.000 \\
\hline $\begin{array}{l}\text { by } \\
\text { Ordinal }\end{array}$ & & $\begin{array}{l}\text { I spend less on } \\
\text { commuting } \\
\text { Dependent }\end{array}$ & 0.308 & 0.046 & 6.757 & 0.000 \\
\hline & & $\begin{array}{l}\text { I shop online more } \\
\text { frequently Dependent }\end{array}$ & 0.338 & 0.051 & 6.757 & 0.000 \\
\hline
\end{tabular}

Source: Own elaboration (2021)

In case of Hungary, Somers'd test was run to determine the assocation between spending less on commuting and online shopping frequency amongst 348 participants from Hungary. There was a moderate, positive correlation between the analysed variables, which was statistically significant $(\mathrm{d}=0.603, \mathrm{p}<0.005)$.

Table 6. Directional Measures (Slovakia) - Somers'd test 2

\begin{tabular}{|c|c|c|c|c|c|c|}
\hline & & & Value & $\begin{array}{c}\text { Asymp. } \\
\text { Stand. } \\
\text { Error }\end{array}$ & $\begin{array}{l}\text { Approx. } \\
\mathrm{T}\end{array}$ & $\begin{array}{l}\text { Approx. } \\
\text { Sig. }\end{array}$ \\
\hline \multirow{3}{*}{$\begin{array}{l}\text { Ordinal } \\
\text { by } \\
\text { Ordinal }\end{array}$} & \multirow{3}{*}{$\begin{array}{l}\text { Somers' } \\
\text { d }\end{array}$} & Symmetric & 0.151 & 0.040 & 3.729 & 0.000 \\
\hline & & $\begin{array}{l}\text { I spend less on } \\
\text { commuting } \\
\text { Dependent }\end{array}$ & 0.144 & 0.039 & 3.729 & 0.000 \\
\hline & & $\begin{array}{l}\text { I shop online more } \\
\text { frequently Dependent }\end{array}$ & 0.158 & 0.042 & 3.729 & 0.000 \\
\hline
\end{tabular}

Source: Own elaboration (2021)

In case of Slovakia, Somers'd test was run to determine the assocation between spending less on commuting and online shopping frequency amongst 514 participants from Slovakia. There was a weak, positive correlation between the analysed variables, which was statistically significant $(d=0.158, p<0.005)$. Based on the obtained results we accept the alternative hypothesis and reject the corresponding nullhypothesis for both countries.

\section{Conclusion}

Thanks to the research examinations it can be stated that there is a significant relationship between job losses and attitudes towards savings for both respondent groups. It means that those respondents who had lost their job changed their saving behaviour. Moreover, it is presumable, that these people will be much more conscientious about their financial affairs. The results showed that there is a positive correlation between increased housing expenditures and shopping reconsideration among respondents. As people have started to work from home during the pandemic, most of them realised that their monthly housing expenditures increased as a result of staying at home for months. We found out that there is a moderate, positive correlation between spending less on commuting and online shopping frequency in the case of Hungarian respondents. In the case of Slovak respondents, there was 
a weak, positive correlation between the analysed variables. Presumably, those people who do not commute to work, save some money. Furthermore, as they do not have to leave their house every day, maybe they will not go shopping, and to avoid being infected, they choose online purchasing. It is indispensable to acknowledge limitations that could be a basis for further research. In spite of the fact that people's spending and saving behaviour change as a result of the examined factors, we did not focus on respondents' financial situation, which could be also relevant. As claimed by Kappes et al. (2020), those who observe that wealthy people spend a lot, are willing to spend a significant proportion of their salaries even if they become more financially vulnerable. Based on Hintošová and Kubíková (2019), people with higher incomes are not only willing to spend fortune for products but they also insist on higher quality what people with lower incomes generally can't afford. We reckon that this is a psychological effect of deeper emotions such as being recognized by society which can lead to irrational spendings. Furthermore, the findings declared that those respondents who spend less on commuting during the pandemic, are more willing to shop online more often, but we did not focus on how much money they saved thanks to working from home. It would be worth examining in future research the post-pandemic trends regarding the consumers' behaviour.

\section{Acknowledgements}

This research was funded by PALLAS ATHÉNÉ DOMUS FOUNDATION, grant number PADE- 138/2019(10.25.) - 4 .

\section{References}

1. Balcerowicz-Szkutnik, M. (2018). The impact of globalisation processes on changes in the consumption model - an attempt to evaluate. $18^{\text {th }}$ International Scientific Conference Globalization and Its Socio-Economic Consequences (pp. 22-29).

2. Beck, M. J., \& Hensher, A. D. (2020). Insights into the impact of COVID-19 on household travel and activites in Australia - The early days of easing restrictions. Transport Policy, 99, 95-119.

3. Binder, C. (2020). Coronavirus Fears and Macroeconomic Expectations. The Review of Economics and Statistics, 102(4), 721-730.

4. Borkowski, P., Gutta, J. M., \& Jarosz, SZ. A. (2021). Lockdowned : Everyday mobility changes in response to COVID-19. Journal of Transport Geography, 90.

5. Cohen, J. (1988). Statistical Power Analysis for the Behavioral Sciences. 2nd ed. Hillsdale, NJ : Lawrence Erlbaum Associates, Publishers.

6. Dulam, R., Furuta K., \& Kanno, T. (2021). Quantitative decision-making model to analyze the post-disaster consumer behavior. International Journal of Disaster Rick Reduction, 61.

7. Furnham, A., \& Cheng, H. (2019). Factors influencing adult savings and investment : Findings from a nationally representative sample. Personality and Individual Differences, 151(1).

8. Hintošová, B. A., \& Kubíková, Z. (2019). Casual Links between Foreign Direct Investments and Innovation Performance. EuroScientia. 1st ed.

9. Jordà, Ò., Singh, R. S., \& Taylor, M. A. (2021). Longer-Run Economic Consequences of Pandemics. The Review of economics and Statistics, 1-29. 
10. Kappes, B. H., Gladstone, J, J., \& Hershfield, E. H. (2020). Beliefs about Whether Spending Implies Wealth. Journal of Consumer Research, 48(1), 1-21.

11. KSH. (2021). A népesség száma, január 1. report. Hungary: Központi Statisztikai Hivatal. http://www.ksh.hu/

12. Liebetrau, A. M. (1983). Measures of association. Thousand Oaks, CA : Sage.

13. Navickas, V., Petroké, I., \& Bačiuliené, V. (2020). Motives of participation in the sharing economy: Tourism sector case. Acta Oeconomica Universitatis Selye, 9(2).

14. Pascual-Saez, M., Cantarero-Prieto, D., \& Pires Manso, J. R. (2019). Does population ageing affect savings in Europe ? Journal of Policy Modeling, 42(2).

15. Rodgers, L. P. (2020). The impact of paid family leave on household savings. Labour Economics, 67.

16. Roth, Ch., \& Wohlfart, J. (2020). How Do Expectations about the Macroeconomy Affect Personal Expectations and Behavior? The Review of Economics and Statistics, 102(4), 731-748.

17. Shamshiripour, A., Rahimi, E., Shabanpour, R., \& Mohammadian, A. K. (2020). How is COVID-19 reshaping activity-travel behavior? Evidence from a comprehensive survey in Chicago. Transportation Research Interdisciplinary Perspectives, 7.

18. Silva, F. J. F., Câmara, G. F. M., Vieira, J. A. C., \& Santos, C. A. S. M. (2020). Is the spending behaviour of tourists affected by low cost carriers' operation ? Some empirical evidence. Tourism Management Perspectives, 33.

19. Somers, R. H. (1962). A new asymetric measure of association for ordinal variables. American Sociological Review, 27, 799-811.

20. ŠÚSR. (2020). Štatistická ročenka regiónov Slovenska: report. Slovakia: Štatistický úrad Slovenskej republiky.

21. Walker, B. F., \& Ugoni, A. (1995). The Chi square test : an introduction. COMSIG Review, 4(3), 61-64.

22. Wiley, W. D. (1999). Biostatistics : A Foundation for Analysis in the Health Sciences. 7th edition. New York : John Wiley \& Sons. 